DOI: https://doi.org/10.24127/ajpm.v9i2.2686

\title{
PENGEMBANGAN DESAIN DIDAKTIS UNTUK MENGATASI LEARNING OBSTACLE PADA MATERI DIMENSI TIGA
}

\author{
Nelly Fitriani $^{1^{*}}$, Gida Kadarisma ${ }^{2}$, Risma Amelia ${ }^{3}$ \\ ${ }^{1,2,3}$ Pendidikan Matematika, IKIP Siliwangi, Cimahi, Indonesia \\ *Corresponding author. Jln Terusan Jenderal Sudirman, Kota Cimahi, Jawa Barat, Indonesia \\ E-mail: $\quad$ nhe.fitriani@gmail.com ${ }^{1 *}$ \\ gidakadarisma@gmail.com ${ }^{2)}$ \\ risma.gembil@gmail.com $^{3)}$
}

Received 20 February 2020; Received in revised form 11 June 2020; Accepted 20 June 2020

\begin{abstract}
Abstrak
Penelitian ini bertujuan untuk mengetahui jenis Learning obstacles yang terjadi pada siswa dalam materi dimensi tiga serta untuk mengetahui desain didaktis yang digunakan dalam mengatasi Learning obstacle. Desain didaktis yang dikembangkan berupa bahan ajar yang disusun berdasarkan empat hal yaitu Learning obstacle yang terjadi, learning trajectory, proses abstraksi siswa serta teori situasi didaktis. Metode penelitian yang digunakan adalah metode kualitatif dengan pendekatan Desain didaktis. Subjek dalam penelitian ini adalah siswa kelas X SMAN 4 Cimahi sebanyak 35 siswa, dengan instrumen berupa Tes Kemampuan Responden soal uraian sebanyak 5 soal serta lembar validasi bahan ajar dari validator ahli. Hasil penelitian menunjukan, jenis Learning obstacle yang terjadi pada siswa adalah Didactical Obstacle, Ontogenic Obstacle, serta Epistemologi obstacle. Kemudian dibuatlah desain didaktis hipotesis yang diimplementasikan sebanyak 6 pertemuan dengan presentase validasi dari validator ahli sebesar $69,5 \%$, analisis retrosfektif dilakukan untuk menganalisis respon siswa atas desain didaktis hipotesis, karena masih terdapat ketidaksesuaian respon siswa dan Epistemologi obstacle masih ditemukan maka dibuatlah desain didaktis revisi dengan presentase validasi meningkat menjadi $76 \%$ dengan kategori valid. Berdasarkan implementasi, desain didaktis ini dapat mengatasi learning obstacle yang dialami siswa pada materi dimensi tiga.Implikasi dari penelitian ini, baiknya bahan ajar yang diberikan pada siswa harus disusun berdasarkan kebutuhan siswa yang, mencakup analisis learning obstacle serta lintasan belajar siswa agar tujuan pembelajaran dapat tercapai.
\end{abstract}

Kata kunci: Desain didaktis; dimensi tiga; learning obstacle.

\begin{abstract}
This study aims to determine the characteristics of Learning obstacles that occur in students in the three dimensional material as well as to find out the didactic designs used in overcoming Learning obstacles. Didactic design developed in the form of teaching materials are arranged based on four things, namely learning obstacle that occurs, learning trajectory, didactical situation theory and the process of abstraction. The research method used is a qualitative method with a didactic design approach. The subjects in this study were 35 students of class X SMAN 4 Cimahi, with instruments in the form of Respondents' Ability Tests about 5 questions and validation sheets of teaching materials from expert validators. The results showed that the characteristics of Learning obstacle that occurred in the three dimensional material were Ontogenic Obstacle, Didactical Obstacle and Obstacle Epistemology. Then a didactic design was made which was implemented as many as 6 meetings with a validation percentage of $69.5 \%$ expert validator, a retrospective analysis was carried out to analyze the students' responses to the didactic hypothesis design, because there were still mismatches of student responses and obstacle epistemology was still found. the validation percentage increased to $76 \%$ with a valid category. Based on the implementation, this didactic design can overcome the learning obstacles experienced by students in the three dimensional material. The implications of this study, the good teaching materials provided to students must be arranged based on the needs of students which, including analysis of learning obstacles and student learning trajectories so that learning objectives can be achieved.
\end{abstract}

Keywords: Didactical design; learning obstacle; three dimensional. 
DOI: https://doi.org/10.24127/ajpm.v9i2.2686

\section{PENDAHULUAN}

Matematika dan pembelajaran matematika adalah dua hal yang tidak dapat dipandang secara parsial, karena pesatnya ilmu matematika dipengaruhi oleh pembelajaran matematika di tingkat sekolah dan Perguruan Tinggi. Kajian dalam matematika salah satu diantaranya adalah geometri. Menurut (Abdussakir, 2010) karena banyak konsep yang termuat dalam matematika, geometri menempati posisi khusus pada kurikulum matematika.

Menurut (Purbasari et al., 2013) Geometri adalah bidang matematika yang didalamnya mempelajari mengenai titik, garis, bidang serta ruang juga mempelajari mengenai ukuran, sifat, dan keterkaitan satu dengan yang lainnya, jika dibandingkan dengan materi lain geometri dianggap paling sulit dipelajari. Menurut Piaget bahwa anak yang berumur 11 atau 12 tahun ke atas berada pada tahap operasi formal, pada fase ini anak sudah dapat menggunakan operasi konkrit untuk membentuk operasi yang lebih kompleks (Jarvis, 2011). Selanjutnya pada tahap operasi formal, argumen-argumen tanpa dikaitkan dengan benda-benda konkret dapat dioperasikan oleh anak sehingga anak bisa menalar tanpa harus ada objek langsungnya.

Geometri sangat berperan pentng dalam pembelajara matematika, hal ini sejalan dengan (Depdiknas, 2006) yang menyatakan bahwa materi pokok geometri menyumbang sekitar $40 \%$ dari seluruh materi pokok matematika di SMP/MTs. Geometri tidak hanya berperan dalam membangun proses berpikir matematis siswa tetapi geometri berperan dalam mempengaruhi matapelajaran yang lainnya.

Tes Pemahaman dimensi tiga diberikan kepada sejumlah siswa yang telah memperoleh materi dimensi tiga dengan indikator menentukan jarak serta besar sudut dalam bangun ruang. Dari hasil tes yang diperoleh, sebagian siswa belum menguasai konsep sudut yang dibentuk dari dua garis yang saling bersilangan, jarak dari titik ke garis, jarak dari titik ke bidang, jarak dari bidang ke bidang dan sudut yang dibentuk oleh dua bidang. Dapat disimpulkan siswa mengalami kesukaran dalam memahami sudut yang dibentuk dari dua buah garis yang bersilangan.

Kesukaran yang dialami akan memungkinkan terjadi kesalahan sewaktu menjawab soal tes .Dengan kata lain kesalahan yang dilakukan dalam menjawab soal tes merupakan indikator adanya Learning obstacle yang dialaminya. Oleh karena itu harus ditemukan jenis hambatan belajar dalam proses pengalaman belajar oleh siswa.

Guru matematika dituntut untuk mempunyai kemampuan mengajar yang baik agar materi dapat dipahami oleh siswa (Kadarisma et al., 2019), salah satu faktor yang dapat mengatasi kesulitan belajar siswa adalah dalam membuat bahan ajar guru harus menyusun sedemikian sehingga tujuan dari pembelajaran dapat tercapai. Menurut (Amiripour et al., 2012) guru matematika mempunyai tanggung jawab secara langsung membentuk kesempatan belajar siswa. Saat ini guru hanya mengandalkan buku sumber seadanya. Guru tidak memberikan bahan ajar dari sumber lain. Oleh karena itu, guru dirasa perlu untuk melakukan inovasi pembelajaran dalam hal pemberian bahan ajar yang dapat mengatasi kesulitan belajar siswa.

Menurut (Suryadi, 2010) usaha guru dalam meningkatkan kualitas pembelajaran adalah melalui refleksi tentang keterkaitan atau adanya korelasi antara rancangan dan proses pembelajaran yang sudah dilakukan. Jika 
dalam proses belajar mengajar yang dikembangkan lebih terfokus agar tujuan pembelajaran tercapai, maka isi dari refleksi cenderung terfokus pada hal itu, sehingga masalah mengenai proses yang beragam, hambatan, serta learning trajectory, boleh jadi bukan hal utama dari refleksi itu. Oleh karena itu, alternatif situasi didaktis dan pedagogis yang disusun dalam rangka perbaikan belum tentu hal yang memang sesuai dengan apa yang siswa butuhkan. Hal ini sejalan (Mulyana et al., 2014) Bagi seoreng pendidik selain perlu menguasai konten yang akan diajarkan perlu juga mempunyai pengetahuan terkait siswa dan mampu menciptakan situasi didaktis sehingga proses belajar akan terdorong secara optimal dan dapat menarik minat siswa dalam kegiatan belajar mengajar.

Pengembangan bahan ajar desain didaktis mempunyai peranan yang sangat penting dalam pembelajaran matematika. Hal ini sangat berpengaruh terhadap bagaimana siswa melakukan pembelajaran di kelas (Suryadi, 2010). Bahan ajar merupakan salah satu komponen yang mendukung terciptanya situasi didaktis. Bahan ajar yang dibuat oleh guru harus memuat alternatif pembelajaran untuk mengantisipasi datangnya masalah yang mungkin muncul dalam pembelajaran, serta dapat menggambarkan munculnya upaya memfasilitasi lintasan belajar siswa.

Penelitian mengenai

Pengembangan bahan ajar desain didaktis sudah beberapa dilakukan salah satunya penelitian (Putra et al., 2017) yang meneliti efektifitas desain didaktis dalam materi pemfaktoran, pada penelitian ini disimpulkan bahwa bahan ajar yang dibuat layak digunakan serta membantu peserta didik untuk belajar lebih mandiri dan nyaman dalam proses belajar serta peserta didik sangat tertarik dengan bahan ajar (modul) desain didaktis.
Selain itu Penelitian mengenai bahan ajar desain didaktis oleh (Putra \& Setiawati, 2018), penelitian menggunakan tahapan pengembangan bahan ajar define, design, develope serta dessiminate, materi yang digunakan adalah persamaan garis lurus, hasil penelitian disimpulkan respon siswa terhadap modul sangat baik. Begitupun dengan penelitian (Siti Aisah et al., 2016) mengembangkan bahan ajar desain didaktis pada materi luas permukaan dan volume prisma hasil penelitian menunjukan bahwa desain didaktis yang telah disusun berdasaran teori belajar yang relevan masuk dalam kategori efektif

Pada Penelitian ini akan memfokuskan desain didaktis pada materi dimensi tiga yang disusun berdasarkan Learning obstacle yang dialami siswa pada tes responden awal. Berdasarkan pemaparan dari latar belakang, tujuan penelitian ini adalah untuk menelaah karakteristik learning obstacles yang dialami siswa dalam menyelesaikan soal pada materi dimensi tiga dan bagaimana desain didaktisnya.

\section{METODE PENELITIAN}

Metode penelitian dalam penelitian ini adalah metode kualitatif dengan pendekatan Penelitian Desain Didaktis (DDR). Metode Penelitian Desain Didaktis merupakan penelitian yang melalui tiga tahapan, yang pertama adalah analisis situasi didaktis yang dituangkan dalam Desain Didaktis Hipotesis, yang kedua adalah analisis metapedadidaktik yaitu impelentasi dari desain didaktis yang telah dibuat, dan analisis retrosfektif.

Instrumen dalam penelitian ini adalah Tes Kemampuan Responden (TKR) yang terdiri atas 5 soal uraian, Tes Kemampuan Responden diberikan sebanyak dua kali, yaitu TKR awal dan TKR akhir. Sebelumnya dilakukan uji coba untuk mengukur validitas dan reliabilitas soal, diperoleh koefesien 
validitas sebesar 0,76 masuk kedalam kategori tinggi, sedangkan koefesien reliabilitas cronbach alfa sebesar 0,67 masuk kedalam kategori sedang. Adapun indikator pada soal TKR adalah:

1. Menentukan garis yang saling sejajar, bersilangan dan berpotongan

2. Menentukan Jarak Titik Ke titik serta titik ke rusuk

3. Menentukan jarak titik ke bidang

4. Menentukan jarak garis ke bidang

5. Menentukan sudut yang dibentuk dari dua buah garis

Tujuan diberikan TKR awal adalah untuk mengetahuil learning obstacle terkait konsep dimensi tiga. Pada TKR akhir instrumen digunakan untuk menganalisis apakah keberadaan learning obstacle masih ada atau tidak setelah desain didaktis diimplementasikan. Sebelum dilaksanakan TKR, instrumen tes terlebih dahulu dilakukan validasi melalui judgment ahli

Populasi dalam penelitian ini adalah siswa SMA N 4 Cimahi, Sampel diperoleh secara acak diperoleh kelas X4 sebanyak 35 siswa. Responden pada kelompok pertama adalah responden yang akan mengikuti Tes Kemampuan Responden awal, yakni mereka siswa yang sudah mendapatkan materi dimensi tiga kelas XI.

Untuk menilai validitas bahan ajar yang telah dibuat dilakukan penilaian oleh validator ahli sebanyak 4 orang dengan menggunakan lembar validasi instrumen oleh ahli, dengan 4 buah pilihan (1 dari 12 butir pertanyaan). Kriteria skor validasi disajikan pada Tabel 1 (Suprianto et al., 2020).

Tabel 1. Kriteria validitas instrumen.

\begin{tabular}{cc}
\hline Skor & Kriteria \\
\hline $75<\% \leq 100$ & Valid \\
$56<\% \leq 75$ & Cukup Valid \\
$39<\% \leq 56$ & Kurang Valid \\
$\% \leq 39$ & Tidak Valid \\
\hline
\end{tabular}

Selanjutnya, dari Tabel 1 akan dihitung rerata dari masing masing lembar validasi dari validator ahli. Langkah analisis data pada penelitian ini yaitu reduksi data hasil TKR serta hasil implementasi desain didaktis dengan merangkum dan memfokuskan kepada hal-hal yang penting, kemudian dilakukan penyajian data dalam bentuk uraian yang bersifat naratif setelah itu dilakukan verifikasi yang didasarkan pada data-data yang valid kemudian pengambilan kesimpulan dari hasil analisis TKR dan analisis respon siswa.

\section{HASIL DAN PEMBAHASAN}

Tes Kemampuan Reponden (TKR) awal kepada siswa kelas XI yang telah mempelajari materi dimensi tiga, kemudian menganalisis Learning obstacle yang terjadi berdasarkan karakteristik dari masing-masing hambatan, TKR awal dilaksanakan pada bulan Mei 2017 dilaksanakan di SMAN 4 Cimahi, dari learning obstacle yang ditemukan pada hasil TKR awal kemudian peneliti menyusun desain didaktis yang dapat mengatasi learning obstacle yang ditemukan. Desain didaktis yang dibuat berdasarkan learning obstacle, learning trajectory, teori situasi didaktis dan proses abstraksi.

Penerapan desain didaktis dilaksanakan sebanyak 6 kali pertemuan (6 Lesson Design). Berikut ini karakteristik Learning obstacle yang ditemukan pada saat Tes Kemampuan Responden (TKR) awal:

\section{Ontogenic Obstacle}

Ontogenic obstacle adalah hambatan belajar siswa dikarenakan adanya proses loncatan berfikir siswa yaitu ketidaksesuaian antara pembelajaran atau desain didaktis yang diberikan tidak sesuai dengan tingkat berpikir siswa, 
ontogenic ini terjadi kebanyakan pada soal nomor 5 dengan indikator meminta menentukan sudut yang dibentuk dua buah (AG dan $\mathrm{AB}$ ) garis pada prisma ABC.EFG.

Dari analisis pengerjaan jawaban siswa loncatan berpikir siswa terjadi saat siswa diminta menentukan sudut yang dibentuk dua buah garis terjadi loncatan dari berpikir analitik ruang menjadi penggunaan aturan cosinus $\operatorname{Cos} G=$ $\frac{A G^{2}+B G^{2}-A B}{2 A G . B G}$, hal ini terjadi bukan hanya dari 1 atau 2 siswa saja, namun dari 50 siswa hampir $70 \%$ menjawab hal yang demikian. Kemudian melakukan wawancara terstruktur dengan beberapa siswa yang menjawab dengan loncatan berpikir tersebut, mereka beranggapan bahwa hal tersebut dapat dikerjakan langsung menggunakan aturan cosinus tanpa harus memperhatikan unsur-unsur lain yang telah diketahui dalam soal TKR, dengan menggunakan rumus aturan cosinus mengakibatkan siswa bisa saja lupa rumusnya seperti apa yang terjadi pada jawaban siswa, rumus yang digunakan tidak tepat sehingga jawabannyapun salah.

\section{Epistemologi obstacle}

Epistemologi obstacle paling banyak ditemukan dalam TKR awal ini, Epistemologi obstacle dikarenakan keterbatasan konteks yang dimiliki oleh siswa, beberapa contoh Epistemologi obstacle dalam TKR awal yaitu pada soal nomor 1a, 1b dan 1c, dengan indikator menentukan kedudukan dua buah garis dalam kubus ABCD. EFGH, kebanyakan jawaban siswa sudah benar, namun hanya menyebutkan 1 garis saja yang sejajar, Siswa menjawab bahwa garis yang sejajar dengan $\mathrm{EH}$ adalah ruas garis FG saja, padahal ada garis BC dan $\mathrm{AD}$ yang sejajar pula, begitupun pada soal 1b dan 1c Epistemologi obstacle lainnya adalah pada soal nomor $2 b$.
Pada soal berikutnya peneliti meminta siswa untuk menghitung jarak dari satu titik ke suatu rusuk dalam suatu kubus ABCD.EFGH. Hasil pengerjaan oleh responden Siswa menjawab bahwa jarak titik A ke rusuk HG merupakan garis AT dimana ia menggambarkan titik $\mathrm{T}$ sebagai titik tengah dari rusuk HG. Siswa tersebut mengalami keterbatasan konsep ia tidak tahu konsep jarak titik ke garis, bahwa jarak titik ke garis merupakan jarak terpendek yang dilalui garis dan titik tersebut.

\section{Didactical Obstacle}

Didactical Obstacle merupakan kesulitan belajar yang diakibatkan bahan ajar dan pengajaran yang diberikan oleh guru, kemudian dilakukan wawancara dan observasi dalam pembelajaran yang dilakukan oleh guru, ternyata guru masih terlalu prosedural dalam memberikan contoh penyelesaian soal, kecenderungan guru dalam mengajar yaitu menerangkan materi kemudian memberi contoh soal dan memberi latihan, hal ini mengakibatkan keterbatasan kemampuan siswa dalam menghadapi masalah-masaah yang baru, ini terlihat dalam menyelesaikan soal tes kemampuan responden (TKR) awal siswa cenderung prosedural dalam menyelesaikan soal, sehingga menghambat daya nalar siswa. Salah satu contoh dalam Didactical Obstacle yaitu ditemukan pada soal nomor 2a, siswa diminta untuk menentukan jarak titik A ke titik G sebagai berikut: Sebuah Kubus ABCD. EFGH dengan panjang rusuk $5 \mathrm{~cm}$. Tentukan : Jarak titik A ke titik G!

Pada soal tersebut siswa menjawab bahwa jarak titik A ke titik G merupakan sebuah diagonal ruang dari kubus, jadi menurut kebanyakan siswa jika panjang rusuk kubus adalah $5 \mathrm{~cm}$ maka panjang diagonal ruangnya adalah $5 \sqrt{3} \mathrm{~cm}$, hal 
ini tidak salah, namun ketika peneliti mewawancarai siswa tersebut ia beralasan bahwa setiap panjang diagonal ruang suatu kubus adalah a $\sqrt{3}$ dengan a adalah panjang dari rusuk tersebut tanpa ia mengetahui darimana rumus itu ia dapatkan, ia mengetahui hal tersebut dari apa yang guru ajarkan sesuai dengan buku ajar yang digunakan.

Setelah karakteristik Learning obstacle diidentifikasi dan bahan ajar guru yang digunakan dianalisis, peneliti membuat desain didaktis berdasarkan hal tersebut. Desain didaktis yang dibuat berdasarkan Learning obstacle, learning trajectory, situasi didaktis dan proses abstraksi. Learning obstacles diidentifikasi dari TKR awal, learning trajectory merupakan lintasan belajar siswa sesuai dengan tingkat berpikir siswa berupa urutan materi yang harus dilalui siswa saat pembelajaran berlangsung. Situasi didaktis mencakup kepada beberapa hal yaitu formulasi, aksi , validasi dan instisionalisasi. Pada situasi Aksi siswa mengembangkan strategi sendiri untuk menemukan solusi dari masalah yang diberikan oleh guru, pada tahap formulasi siswa diberi kesempatan untuk menciptakan model sendiri, dilakukan komunikasi dua arah antarsiswa membawa mereka ke suatu strategi. Pada tahap Validasi guru menuntun siswa pada situasi didaktis melalui suatu proses untuk memastikan bahwa mereka menggunakan strategi yang tepat, degan cara demikian kesalahan merupakan titik awal dalam proses mengonstruksi pengetahuan. Pada tahap Institusionalisasi siswa mengubah pengetahuan mereka sebelumnya menjadi pengetahuan baru untuk memecahkan masalah. Abstraksi Merupakan keteraturan dari setiap proses pembelajaran yang akhirnya mendorong siswa untuk dapat menentukan sesuatu sesuai dengan tujuan pembelajaran
Dari keempat hal tersebut dibuat suatu desain didaktis hipotesis berupa chapter design dan Lesson Design yang kemudian disajikan dalam suatu bahan ajar. Lesson Design yang dibuat terdiri dari 6 pertemuan dengan indikator kemampuan yang berbeda-beda. Analisis metapedadidaktis merupakan implementasi bahan ajar yang telah disusun oleh peneliti. Respon siswa di luar prediksi yang mucul juga perlu ditindaklanjuti dengan memberikan respon didaktis disesuaikan dengan kondisi yang ada. Bahan ajar yang telah disusun kemudian dinilai oleh validator ahli. Berikut rekapitulasi dari penilaiannya :

Tabel 2. Skor validasi desain didaktis hipotesis.

\begin{tabular}{cc}
\hline Validator & Persentase \\
\hline Validator 1 & $65 \%$ \\
Validator 2 & $73 \%$ \\
Validator 3 & $69 \%$ \\
Validator 4 & $71 \%$ \\
Rata-rata & $69.5 \%$ \\
\hline
\end{tabular}

Dari Tabel 2 diperoleh rata-rata persentase penilaian masing-masing validator sebesar $69.5 \%$, berdasarkan kriteria maka bahan ajar tergolong dalam klasifikasi cukup valid.

Hasil implementasi bahan ajar desain didaktis menunjukkan, dengan desain didaktis bahan ajar dimensi tiga, siswa lebih menguasai konsep jarak titik, garis dan bidang pada bangun ruang, serta konsep sudut yang dibentuk oleh garis dan bidang, dengan permasalahanpermasalaan kontekstual yang tertuang dalam bahan ajar siswa menjadi lebih biasa dengan permasalahanpermasalahan dimensi tiga dengan konteks yang berbeda, siswa lebih mandiri dalam mengerjakan soal.

Setelah tahap implementasi dilaksanakan yaitu sebanyak 6 
pertemuan kemudian dilakukan Tes Kemampuan Responden (TKR) akhir, untuk melihat apakah masih terdapat learing obstacle yang terjadi setelah implementasi desain didaktis dilakukan.

Setelah dilakukan analisis TKR akhir, tidak ditemukan lagi Ontogenic Obstacle dan Didactical Obstacle, namun masih terjadi Epistemologi obstacle walaupum kuantitasnya tidak sebanyak saat TKR awal yaitu mengenai jarak garis pada bidang. Berikut ini hasil TKR akhir:

\section{Ontogenic Obstacle}

Pada TKR akhir, tidak ditemukan lagi Ontogenic Obstacle yaitu loncatan berpikir dari geometri pada rumus aturan cosinus pada soal nomor 5 seperti pada TKR awal. Kebanyakan siswa sudah tepat dalam menentukan sudut antara dua buah garis. hal ini dikarenakan bahan ajar saat metapedadidaktis disusun agar loncatan berpikir siswa tidak terjadi.

\section{Epistemologi obstacle}

Epistemologi obstacle pada saat TKR awal pada soal nomor 1 sudah tidak ditemukan lagi yaitu keterbatasan konteks mengenai kedudukan garis yang saling sejajar, berpotongan dan bersilangan dalam suatu kubus, begitupun pada soal nomor 4 mengenai keterbatasan konteks mengenai

jarak garis pada bidang dalam kubus, meskipun masih banyak siswa yang keliru mengenai garis yang tegak lurus bidang, namun jumlah siswa yang keliru tidak sebanyak pada TKR awal, ini menjadi bahan pertimbangan dalam penyusunan desain didaktis revisi

Epistemologi obstacle yang terjadi pada TKR awal sudah tidak terjadi lagi pada TKR akhir, yaitu keterbatasan konteks yang dialami siswa mengenai konsep kesejajaran garis pada suatu kubus, pada soal TKR nomor 1 ditemukan keterbatasan konsep yaitu siswa tertukar konsep garis yang bersilangan dengan garis yang berpotongan, namun pada TKR akhir tidak ditemukan lagi, hal ini dikarenakan pada desain didaktis disusun untuk menguatkan konsep kedudukan titik, garis dan bidang sehingga meminimalisir terjadinya Epistemologi obstacle.

\section{Didactical Obstacle}

Didactical Obstacle terjadi karena ada kekeliruan bahan ajar yang tidak sesuai dengan proses berpikir siswa, hal ini bisa diakibatkan karena bahan ajar atau pembelajaran yang dibawakan oleh guru. Didactical Obstacle pada saat di pada soal nomor 2 sudah tidak terjadi lagi.

Pada saat TKR awal, Didactical Obstacle terjadi pada soal nomor 2, yaitu hampir semua siswa menentukan diagonal ruang dan bidang dengan rumus $\mathrm{a} \sqrt{2}$ dan $\mathrm{a} \sqrt{3}$ tanpa mengetahui dari mana hal itu didapatkan, mereka mengetahui hal tersebut dari bahan ajar yang digunakan dan pembelajaran yang dibawakan oleh guru, namun setelah diimplementasikan desain didaktis, Didactical Obstacle tersebut tidak terjadi lagi.

Analisis retrosfektif yaitu analisis desain didaktis setelah pelaksanaan implementasi. Hasil analisis metapedadidaktik kemudian dilakukan analisis retrosfektif, yang mengaitkan hasil pengembangan desain bahan ajar hipotesis dengan hasil analisis implementasi desain didaktis. Tahapan analisis retrosfektif berakhir pada pengembangan situasi didaktis revisi sebagai perbaikan dari desain didaktis yang telah diimplementasikan.

Dari desain didaktis hipotesis, dibuat desain didaktis revisi yang dibuat peneliti berdasarkan perbaikan desain didaktis hipotesis dan analisis TKR 
DOI: https://doi.org/10.24127/ajpm.v9i2.2686

akhir, diantaranya adalah beberapa pernyataan pada situasi aksi dan penambahan perkiraan waktu. Beberapa respon yang tidak terduga sebelumnya, yang merupakan catatan selama implementasi telah ditambahkan dalam desain didaktis revisi. Berikut revisi pada desain didaktis :

Lesson Design 1 : Respon siswa pada setiap permasalahan yang ada dalam bahan ajar cukup baik sesuai dengan prediksi guru, pada tahap aksi, formulasi dan validasi sudah berjalan dengan baik, sehingga pada Lesson Design ini tidak diperlukan revisi lagi

Lesson Design 2 : Pada Lesson

Design ini, diperlukan sedikit revisi, karena ada respon siswa yang tidak sesuai dengan prediksi yaitu dalam menentukan pengertian kedudukan garis yang tegak lurus pada bidang, pada bahan ajar siswa masih sulit untuk menyimpulkan pengertian kedudukan garis tegak lurus bidang, dalam kesimpulan akan ditambahkan dengan kata-kata "dengan semua garis pada bidang..."

Lesson Design 3 : Respon siswa pada setiap permasalahan yang ada dalam bahan ajar cukup baik sesuai dengan prediksi guru, pada tahap aksi, formulasi dan validasi sudah berjalan dengan baik, sehingga pada Lesson Design ini tidak diperlukan revisi lagi

Lesson Design 4 : Saat Lesson

Design 4 pada permasalahan 1 siswa merasa ambigu dengan perintah dari soal seperti pada Gambar 1, Karena banyak siswa yang tidak paham atas perintah dari soal tersebut dan tujuan dimunculkan soal tersebut tidak tepat sasaran, maka model rel kereta api sebagai dua garis yang sejajar aka diganti dengan model dua buah kabel yang sejajar yang dapat dilihat pada Gambar 1

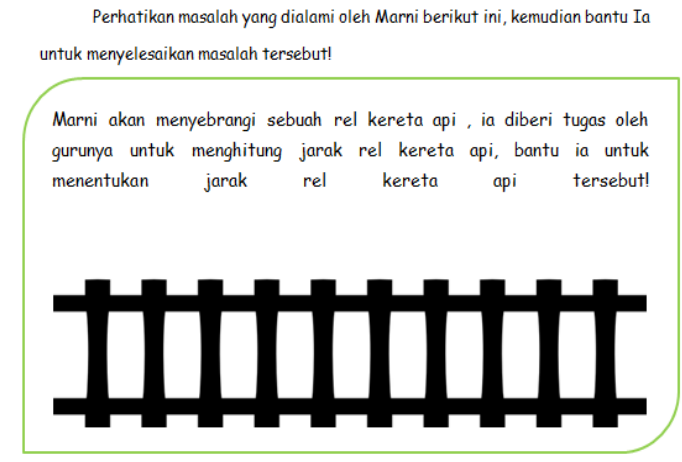

Gambar 1. Desain didaktis hipotesis.

Perhatikan masalah yang dialami oleh Marni berikut ini, kemudian bantu Ia untuk menyelesaikan masalah tersebut!

Marni diberi tugas oleh gurunya untuk menghitung jarak antar kabel seperti pada gambar, bantu Marni untuk menghitungnyal

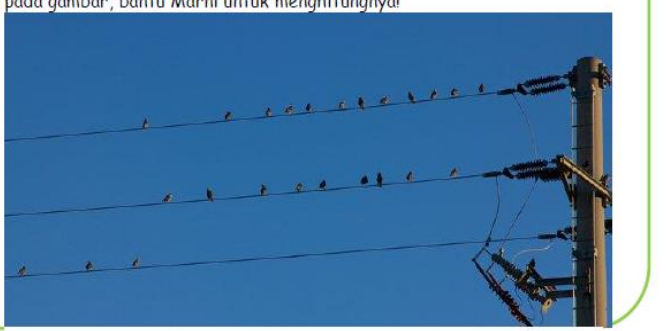

Gambar 2. Desain didaktis revisi.

Agar siswa dapat lebih memahami ilustrasi dua buah garis yang sejajar, maka pada desain didaktis revisi diilustrasikan dengan kumpulan kabel yang terbentang seperti pada Gambar 2 .

Lesson Design 5: Tidak diperlukan revisi pada Lesson Design ini karena respon siswa sudah baik sesuai dengan prediksi guru, namun dalam mengerjakan soal uji kompetensi diperlukan waktu yang lama mengingat soal yang dikerjakan cukup banyak.

Lesson Design 6: Pada pertemuan ini, respon siswa cukup baik dan sesuai dengan prediksi, namun guru harus lebih memotivasi siswa dalam langkah-langkah menentukan sudut yang dibentuk oleh dua buah bidang, karena dalam uji kompetensi masih ada siswa yang tidak mengisi soal tersebut, dan soal uji kompetensi akan ditambah lagi untuk meningkatkan kemampuan siswa. 
DOI: https://doi.org/10.24127/ajpm.v9i2.2686

Setelah desain didaktis diimplementasikan, dilaksanakan Tes Kemampuan Responden Akhir dengan soal yang serupa dengan Tes Kemampuan Responden Awal untuk melihat apakah Learning obstacles yang dialami siswa pada saat TKR awal masih ada atau tidak, setelah dilaksanakan TKR akhir, Ontogenic Obstacles yang dialami siswa yaitu loncatan berpikir dari geometi pada rumus aturan cosinus sudah tidak terjadi lagi, kemudian Epistemologi obstacle masih terjadi namun kuantitasnya tidak sebanyak pada saat TKR awal, masih terdapat keterbatasan konsep mengenai garis tegak lurus bidang, namun untuk Epistemologi obstacle yang lainnya sudah tidak nampak, begitupun dengan Didactical Obstacle yang terjadi pada saat TKR awal sudah tidak nampak lagi. Berikut ini hasil penilaian validator ahli terhadap desain didaktis revisi yang telah disusun.

Tabel 3. Skor validasi desain didaktis revisi.

\begin{tabular}{cc}
\hline Validator & Persentase \\
\hline Validator 1 & $77 \%$ \\
Validator 2 & $78 \%$ \\
Validator 3 & $70 \%$ \\
Validator 4 & $79 \%$ \\
Rata-rata & $76 \%$ \\
\hline
\end{tabular}

Dari Tabel 3 diperoleh rata-rata presentasi penilaian masing-masing validator terhadap desain didaktis yang telah direvisi sebesar $76 \%$, berdasarkan kriteria maka bahan ajar tergolong dalam klasifikasi valid. Penilaian validator ahli mengalami peningkatan dari $69.5 \%$ desain didaktis hipotesis setelah bahan ajar direvisi persentase menjadi $76 \%$ yang berarti bahan ajar disain didaktis valid untuk digunakan

Pada tes awal ditemukan hambatan siswa dalam mengilustrasikan unsur-unsur pada dimensi tiga, sehingga tidak jarang siswa kesulitan dalam membangun proyeksi jarak dan sudut, namun setelah diberikan desain didaktis yang dikembangkan sesuai kesulitan siswa dan lintasan belajar siswa terjadi perubahan yang signifikan pada tes akhir, pemahaman siswa menjadi lebih terbangun secara mandiri sehingga hambatan belajar dapat diminimalisir. Hal ini dikarenakan bahan ajar yang disusun secara terstruktur serta sesuai permasalahan kontekstual yang mudah dipahami oleh siswa. Hal ini sejalan dengan penelitian (Sulistiawati et al., 2015) hasil penelitian menunjukkan kesulitan-kesulitan siswa dalam meyelesaikan soal menjadi berkurang karena desain didaktis yang digunakan efektif. Serta respon siswa terhadap bahan ajar positif. Dari pemaparanpemaparan diatas maka Learning obstacle dapat diatasi dengan menggunakan bahan ajar yang sesuai dengan kebutuhan siswa dan lintasan belajar siswa.

Oleh karena itu kemampuan seorang guru dalam merancang pembelajaran sangat dibutuhkan (Kadarisma \& Amelia, 2018). Bahan ajar yang tepat kesulitan belajar siswa dapat diatasi dengan baik (Nugraha et al., 2015). Dengan menganalisis lintasan belajar siswa serta membuat desain didaktis yang tepat guru dapat memfasilitasi kesulitan belajar siswa dengan tepat, sehingga tujuan belajar siswa dapat tercapai.

\section{KESIMPULAN DAN SARAN}

Kesimpulan dari penelitian ini adalah terdapat 3 jenis karakteristik Learning obstacle yang ditemukan pada materi dimensi tiga yaitu Epistemologi obstacle, Ontogenic Obstacle, dan Didactical Obstacle. Desain didaktis yang dikembangkan dapat dikategorikan 
valid serta dapat mengatasi Learning obstacle pada materi dimensi tiga.

Adapun saran untuk penelitian selanjutnya diharapkan dapat mengembangkan bahan ajar dengan materi lain, serta tahapannya sampai kepada implementasi bahan ajar revisi agar desain didaktis menjadi maksimal.

\section{DAFTAR PUSTAKA}

Abdussakir. (2010). Pembelajaran Geometri Sesuai Teori Van Hiele. El-Hikmah: Jurnal Kependidikan Dan Keagamaan, 7(2).

Amiripour, Parvaneh, Somayeh, AmirMofidi, \& Ahmad, S. (2012). Scaffolding as effective method for mathematical learning. Indian Journal of Science and Technology, 5(9), 3328-3331.

Depdiknas. (2006). Standar Kompetensi dan Kompetensi Dasar dalam KTSP mata pelajaran matematika Sekolah Menengah Pertama/Madrasah Tsanawiyah. Depdiknas.

Jarvis, M. (2011). Teori-Teori Psikologi, Cet. $X$,. Nusa Media.

Kadarisma, G., \& Amelia, R. (2018). Epistemological Obstacles in Solving Equation of Straight Line Problems. International Conference on Mathematics and Science Education of Universitas Pendidikan Indonesia, 905-910.

Kadarisma, G., Senjayawati, E., \& Amelia, R. (2019). Pedagogical Content Knowledge Pre-Service Mathematics Teacher. Journal of Physics: Conference Series, 1315(1). https://doi.org/10.1088/17426596/1315/1/012068

Mulyana, E., Turmudi, \& Juandi, D. (2014). Model Pengembangan Desain Didaktia Subject Specific
Pedagogy Bidang Matematika Melalui Program Pendidikan Profesi Guru. Jurnal Pengajaran Matematika Dan Ilmu Pengetahuan Alam, 19(2), 141-149.

Nugraha, N., Kadarisma, G., \& Setiawan, W. (2015). Analisis kesulitan belajar matematika materi bentuk aljabar pada siswa smp kelas vii. Journal On Education, 01(02), 323-334.

Purbasari, R. julia, Kahfi, M. S., \& Yunus, M. (2013). Pengembangan Aplikasi Android Sebagai Media Pembelajaran Matematika Pada Materi Dimensi Tiga Untuk Siswa SMA Kelas X. Jurnal Online Universitas Negeri Malang, 1-11. http://lib.unnes.ac.id/3749/

Putra, R. W. Y., Nurwani, N., Putra, F. G., \& Putra, N. W. (2017). Pengembangan Desain Didaktis Bahan Ajar Materi Pemfaktoran Bentuk Aljabar pada Pembelajaran Matematika SMP. NUMERICAL: Jurnal Matematika Dan Pendidikan Matematika, 1(2), 97-102.

Putra, R. W. Y., \& Setiawati, N. (2018). Pengembangan Desain Didaktis Bahan Ajar Persamaan Garis Lurus. Jurnal Penelitian Dan Pembelajaran Matematika, 11(1).

Siti Aisah, L., Kusnandi, \& Yulianti, K. (2016). Desain Didaktis Konsep Luas Permukaan Dan Volume Prisma Dalam Pembelajaran Matematika Smp. MA TH L I N E: Jurnal Matematika Dan Pendidikan Matematika, 1(1), 1422.

Sulistiawati, S., Suryadi, D., \& Fatimah, S. (2015). Desain Didaktis Penalaran Matematis untuk Mengatasi Kesulitan Belajar Siswa SMP pada Luas dan Volume Limas. Kreano, Jurnal Matematika Kreatif-Inovatif, 6(2), 152-163. 
DOI: https://doi.org/10.24127/ajpm.v9i2.2686

Suprianto, T., Noer, Sri, H., \& Rosidin, U. (2020). Pengembangan Model Pembelajaran Grup Investigation Berbantuan Soal Open Ended untuk Meningkatkan Kemampuan Berpikir Reflektif Matematis. AKSIOMA: Jurnal Program Studi Pendidikan Matematika, 9(1), 7285.

Suryadi, D. (2010). Didactical Design Research (DDR) dalam Pengembangan Pembelajaran Matematika. Prosiding Seminar Nasional. Seminar Nasional Pembelajaran MIPA Di UM Malang. 